\title{
DETERMINATION OF BALLISTIC PROPERTIES ON ARMOX 500T STEEL WELDED JOINT
}

\author{
Ivica Garašić $^{1 *}$ - Maja Jurica ${ }^{1}$ - Dario Iljkić ${ }^{2}-$ Ante Barišić $^{1}$
}

\begin{abstract}
${ }^{1}$ Department of Welded Structures, Faculty of Mechanical Engineering and Naval Architecture, University of Zagreb, Ivana Lučića 5, 10000 Zagreb, Croatia

${ }^{2}$ Department of Materials Science and Engineering, University of Rijeka - Faculty of Engineering, Vukovarska 58, 51000 Rijeka, Croatia
\end{abstract}

\begin{tabular}{l} 
ARTICLE INFO \\
\hline Article history: \\
Received: 16.2 .2018$. \\
Accepted:10.4.2018. \\
\hline Keywords: \\
ARMOX 500T steel \\
Welded joint \\
Ballistic properties \\
\hline DOI: http://doi.org/10.30765/er.39.2.8
\end{tabular}

\section{Introduction}

An armour has three main roles in order to ensure protection and integrity of the combat vehicle and its occupants. These three roles are often described as: absorption of the penetrator's energy and/or transfer of energy to the supporting structure; rebounding or changing of direction of the penetrators away from the vehicle; and deformation of the penetrator [1]. The armour materials were chosen as a function of their intended application, ballistic performance, weight, and price [2]. While some military equipment manufacturers involve the application of lower-density metals such as aluminium and titanium, the selection of steel alloys is still competitive for many ballistic and structural applications. The ability to fabricate armour

\begin{abstract}
:
In this paper, the effect of different hardness filler materials and sequence of welding on the ballistic performance has been investigated. Also, besides the optimization of the ballistic properties, other mechanical testing was carried out in order to achieve wanted mechanical properties along the entire welded joint. The experimental work includes macrostructure analysis, ballistic testing, and hardness testing of steel welded joint. The base material used in the experiment were ARMOX ${ }^{\circledR} 500 T$ plates. In this experiment 3 different filler materials were used. Based on the testing results, it was found out that best ballistic performance of the welded joint is achieved if capping layer is welded with a hardfacing filler material. This distributes the impact energy to a greater area and transfers it to the lower hardness weld layer underneath which then absorbs the rest of the energy.
\end{abstract}

components in both commercial and military operational areas with available equipment and personnel is a major advantage of steel solutions [3]. Quenched and Tempered (Q\&T) steels are used in military applications due to their high hardness, high strength to weight ratio, and excellent toughness. The majority of armour fabrication is performed by fusion welding process and they demand for highest welding quality. The shielded metal arc welding (SMAW) and the flux cored arc welding (FCAW) processes are widely used in fabrication of combat vehicle construction. Due to the heterogeneity induced from welding, base metal (BM), weld metal (WM) and heat affected zone (HAZ) have different mechanical behaviours, which make welded joints complicated under local stress-strain conditions.

\footnotetext{
${ }^{*}$ Corresponding author. Tel.: +385 16168394

E-mail address: ivica.garasic@fsb.hr
} 
Thus, welding is a major factor in the fatigue lifetime reduction of the components [4].

Austenitic stainless steel (ASS) welding consumables are traditionally used for welding of high hardness Q\&T steels as they have higher solubility for hydrogen in austenitic phase [5]. It was recently reported that the presence of the austenitic stainless-steel (ASS) buttering layer between the armour plate [base metal (BM)] and weld metal/hardfaced metal resulted in enhanced ballistic performance and successfully held the weld layers intact when a projectile was fired at interfaces and the heat-affected zone (HAZ) [6]. It was also reported that the ballistic performance of the weld metal is enhanced, resulting in shattering of the projectile [7]. Furthermore, more investigation was carried out in the field of ballistic testing of Q\&T steels used in military applications regarding the effects of different welding consumables on weld quality, welding processes and layered structure combinations [8]. The literature [9-10] states that the ballistic immunity can be improved by sandwiching of hardfaced interlayers in between soft austenitic stainless steel (ASS) welds. Welds welded completely with the hardfaced filler material were shattered under ballistic impact. An overlay of the hardfacing alloy over the ASS welds also shattered, due to extensive cracking in the hardfacing layer. Sandwiched hardfacing alloy weld between the ASS welds, resulted in the occurrence of cracks in the interface between the hardfaced layer and the base metal. This is due to the brittle nature of the interface [10]. The effect of the ASS buttering layer between armour plate (base metal) and weld metal/hardfaced metal improves ballistic performance by the resulting microstructure and hardness distribution. Thus it keeps the weld layers intact when the projectile is fired at interfaces and HAZ. Further investigation is required at the weld centre line (WCL) with different weld layer thickness and joint configuration [6].

\section{The experimental work}

The base material used in the experiment were 8 mm thick ARMOX ${ }^{\circledR}$ 500T plates (dimensions and joint configuration is shown in Fig. 1). In this experiment 3 different filler materials were used. These filler materials were divided into two general groups - austenite stainless steel (ASS) filler material and hardfacing (HF) filler material. The ASS filler material used was Lincoln Electric ${ }^{\circledR}$ MIG 309L Si (diameter of $1.2 \mathrm{~mm}$ ). The hardfacing filler materials used were Durmat ${ }^{\circledR}$ FD 739 (diameter of $1.6 \mathrm{~mm}-\mathrm{HF} 1)$ and Castolin Eutectic ${ }^{\circledR}$ EnDOtec $^{\circledR}$ DO*30 (diameter of $1.2 \mathrm{~mm}-\mathrm{HF} 2$ ). Chemical compositions of the base and filler materials are shown in Table 1.

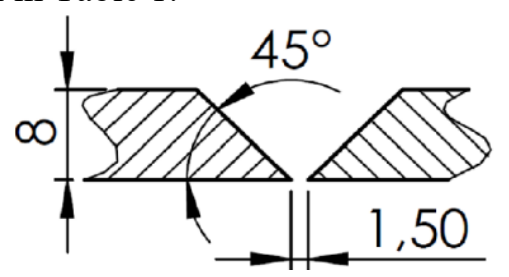

Figure 1. Joint configuration.

Table 1. Chemical composition of the base metal and filler materials

\begin{tabular}{|c|c|c|c|c|c|c|c|c|c|c|c|c|c|c|}
\hline \multirow{2}{*}{ Material } & \multicolumn{14}{|c|}{ Chemical element, wt \% } \\
\hline & $\mathrm{C}$ & $\mathrm{Si}$ & $\mathrm{Mn}$ & $\mathrm{P}$ & $\mathrm{S}$ & $\mathrm{Cr}$ & $\mathrm{Ni}$ & Mo & $\mathrm{B}$ & $\mathrm{N}$ & $\mathrm{Cu}$ & $\mathrm{W}$ & $\mathrm{Nb}$ & $\mathrm{Fe}$ \\
\hline $\begin{array}{l}\text { ARMOX } \\
500 \mathrm{~T}\end{array}$ & 0.32 & 0.4 & 1.2 & 0.015 & 0.01 & 1.01 & 1.81 & 0.7 & 0.005 & - & - & - & - & Bal. \\
\hline $\begin{array}{c}\text { Lincoln } \\
\text { Electric } \\
\text { MIG } \\
\text { 309L Si }\end{array}$ & 0.03 & 0.89 & 2 & 0.02 & 0.01 & 23.5 & 13.7 & 0.28 & - & 0.06 & 0.22 & - & - & Bal. \\
\hline $\begin{array}{l}\text { Durmat } \\
\text { FD } 739\end{array}$ & 1.0 & - & - & - & - & 2.0 & - & 3.3 & 4.4 & - & - & 5.7 & 3.4 & Bal. \\
\hline $\begin{array}{c}\text { Castolin } \\
\text { Eutectic } \\
\text { EnDOtec } \\
\text { DO*30 }\end{array}$ & \multicolumn{14}{|c|}{ The chemical composition is not specified } \\
\hline
\end{tabular}


Before welding of the plates, all of the bevelled edges of the $\mathrm{V}$ groove were buttered with a layer of ASS filler material. According to the literature [8] this layer provides the welded joint with improved ballistic performance. Buttering was carried out by positioning of the plates on copper backing and tilted for $45^{\circ}$. After applying the buttering layer, root pass was welded from the backside of the joint. Before continuing with the welding, other filler passes, root pass and buttering layer were grinded in the middle in order to eliminate possible slag inclusions and to achieve more favourable joint geometry (Fig. 2). Total of 4 different samples were welded all with different welding sequences and filler material combinations. The samples U1, U3 and U4 were welded in total of 6 welding passes and sample U2 was welded in 4 passes. The joints were welded as per the sequence shown in Fig 3 (a - samples U1, U3 and U4; b - sample U2). Welding parameters used to produce all of the samples are presented in Table 2 and Table 3. All samples were welded using pulsed metal transfer and DCEP with no weaving motion. The inter-pass temperature was maintained under $100{ }^{\circ} \mathrm{C}$ during welding of all passes.

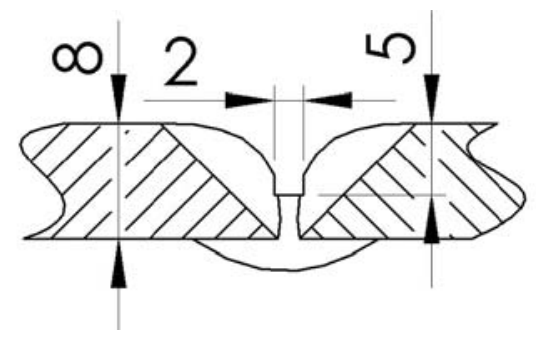

Figure 2. Buttering layer configuration.

Table 2. Welding parameters

\begin{tabular}{|c|c|c|c|c|c|c|}
\hline \multirow{2}{*}{$\begin{array}{l}\text { Welding } \\
\text { parameters }\end{array}$} & \multicolumn{6}{|c|}{ Weld pass } \\
\hline & $\begin{array}{c}\text { Buttering } \\
\text { layer }\end{array}$ & Root pass & Filler pass A & Filler pass $B$ & Filler pass $\mathrm{C}$ & Filler pass D \\
\hline $\begin{array}{l}\text { Heat input, } \\
\mathrm{kJ} / \mathrm{cm}\end{array}$ & 5.07 & 6.33 & 6.33 & 7.27 & 7.24 & 4.8 \\
\hline $\begin{array}{l}\text { Welding } \\
\text { technique }\end{array}$ & Push & Pull & Push & Pull & Pull & Pull \\
\hline CTWD, mm & 6.0 & 7.0 & 7.0 & 7.0 & 10.0 & 18.0 \\
\hline $\begin{array}{c}\text { Shielding } \\
\text { gas }\end{array}$ & $\begin{array}{c}98 \% \mathrm{Ar} / \\
2 \% \mathrm{O}_{2}\end{array}$ & $\begin{array}{c}98 \% \mathrm{Ar} / \\
2 \% \mathrm{O}_{2} \\
\end{array}$ & $\begin{array}{c}98 \% \mathrm{Ar} / \\
2 \% \mathrm{O}_{2} \\
\end{array}$ & $\begin{array}{c}98 \% \mathrm{Ar} / \\
2 \% \mathrm{O}_{2} \\
\end{array}$ & - & $\begin{array}{c}97.5 \% \mathrm{Ar} / \\
2.5 \% \mathrm{CO}_{2}\end{array}$ \\
\hline $\begin{array}{c}\text { Filler } \\
\text { material }\end{array}$ & ASS & ASS & ASS & ASS & HF1 & HF2 \\
\hline
\end{tabular}

Table 3. Weld passes for each sample

\begin{tabular}{|c|c|c|c|c|}
\hline \multirow{2}{*}{ Sample } & \multicolumn{4}{|c|}{ Weld pass } \\
\cline { 2 - 5 } & 1,2 & 3 & 4 & 5,6 \\
\hline U1 & Buttering layer & Root pass & Filler pass A & Filler pass B \\
\hline U2 & Buttering layer & Root pass & Filler pass C & - \\
\hline U3 & Buttering layer & Root pass & Filler pass D & Filler pass A \\
\hline U4 & Buttering layer & Root pass & Filler pass A & Filler pass C \\
\hline
\end{tabular}
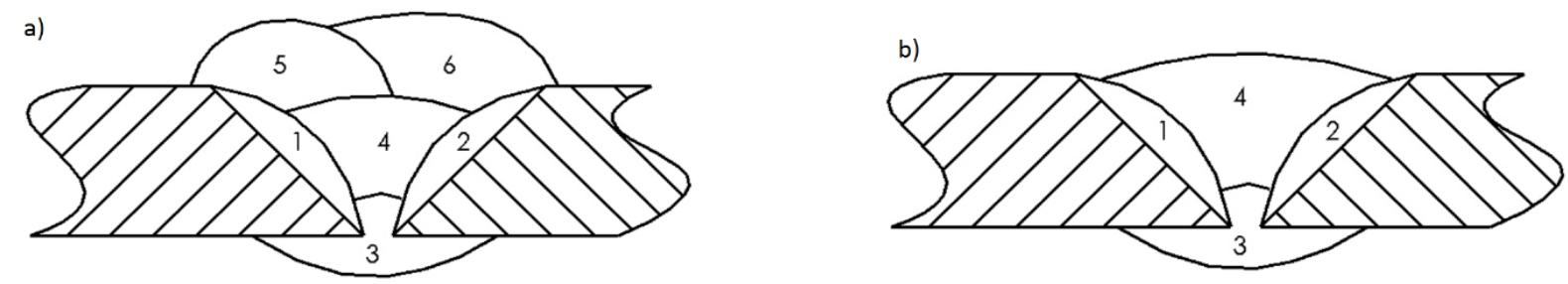

Figure 3. Welding sequences. 
After welding of test specimens, all of the specimens were subjected to standard ballistic testing. The base material, ARMOX 500T, $8 \mathrm{~mm}$ in thickness is designed to withhold ballistic loading of level 2 according to the NATO AEP-55 STANAG 4569 standard. Therefore, the munition type used was standard 7.62 x 51 with copper jacket. Firing was executed with $7.62 \mathrm{~mm}$ tank machine gun from the 10-meter distance. All of the test specimens were shot 4 times at the weld zone.

For the macrograph analysis, samples were water jet cut into dimensions $12 \times 50 \times 8 \mathrm{~mm}$. Afterwards electrochemical etching in $10 \% \mathrm{CrO}_{3}$ acid with sample connected to 4A DCEP for 2 minutes and 15 seconds was done.

\section{The results and discussion}

\subsection{Macrostructure}

Macrostructures of all the welded joints are shown in Fig. 4 to Fig. 7. As can be seen from the mentioned figures, all of the samples (except for sample U2) have a significant reinforcement due to the final two layers. These reinforcements were not grinded because that would affect the ballistic performance of the joints. The welded joints are all homogenous without occurrence of pores or inclusions. A penetration of all weld passes is sufficient and no lack of fusion was noticed. The only difference between the samples is between the sample U2 and all the other samples, and it lies in the deformation of the welded structure. It can be noticed that the sample U2 is less deformed compared to the other samples. This difference is due to smaller overall heat input and therefore less thermal deformations.

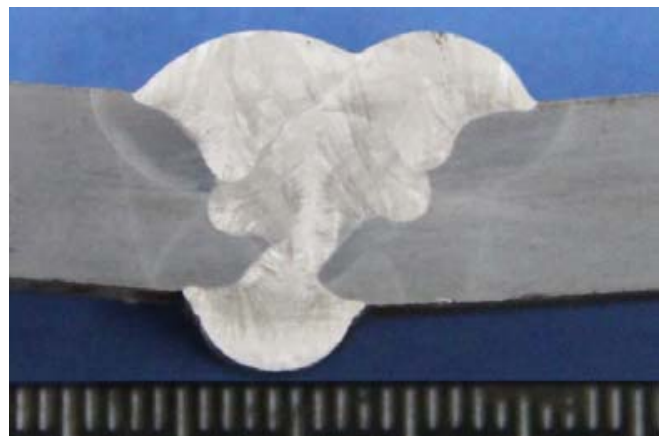

Figure 4. U1 macrograph.

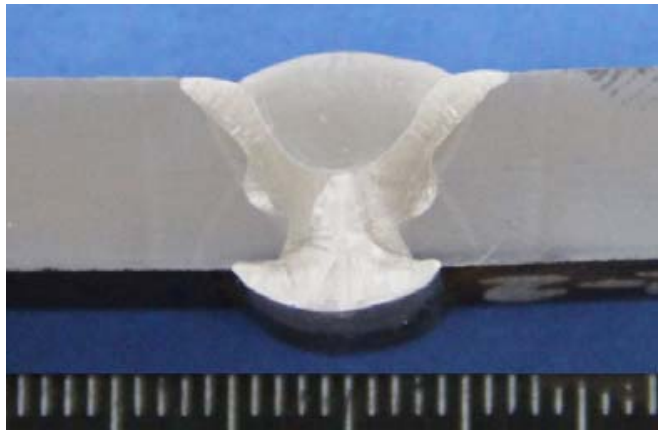

Figure 5. U2 macrograph.

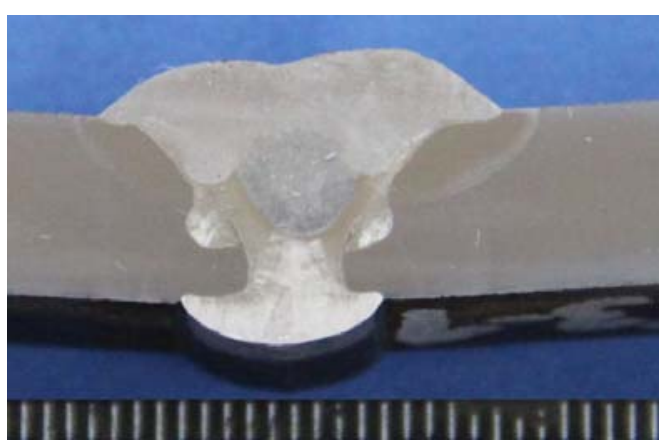

Figure 6. U3 macrograph.

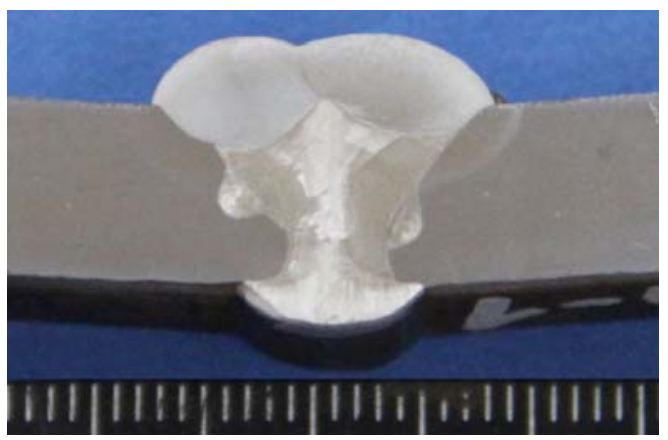

Figure 7. U4 macrograph.

\subsection{Ballistic performance}

As previously mentioned, all of the test samples were subjected to ballistic testing. Additionally, the test plate U1 was shot with 4 extra shots into base material, the test plate U2 was shot extra 4 times into base material with munition calibre $12.7 \mathrm{~mm}$ and the test plate U3 was shot with extra 4 times (two times into the same place in the base material). All of the ballistic test results are shown in Table 4. 
Table 4. The ballistic results with breach types and degrees of damage

\begin{tabular}{|c|c|c|c|c|}
\hline Sample & Hit & Location & Damage & Breach type \\
\hline \multirow{5}{*}{ U1 } & H1-1 & $\mathrm{WM}$ & Partial breach & Shear through HAZ \\
\hline & $\mathrm{H} 1-2$ & FL and HAZ & Total breach & Plugging \\
\hline & $\mathrm{H} 1-3$ & WM & Total breach & Plugging \\
\hline & $\mathrm{H} 1-4$ & WM & Total breach & $\begin{array}{l}\text { Plugging, bullet left } \\
\text { trapped in perforation }\end{array}$ \\
\hline & $\begin{array}{l}\text { H1-5, H1-6, } \\
\text { H1-7, H1-8 }\end{array}$ & $\mathrm{BM}$ & No significant damage & 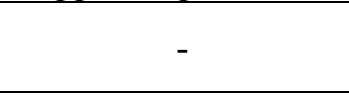 \\
\hline \multirow{4}{*}{$\mathbf{U} 2$} & $\mathrm{H} 2-1$ & WM & Total breach & Plugging \\
\hline & $\mathrm{H} 2-2, \mathrm{H} 2-3$ & FL & Total breach & Plugging \\
\hline & $\mathrm{H} 2-4$ & HAZ & Total breach & Plugging \\
\hline & $\begin{array}{l}\mathrm{H} 2-5, \mathrm{H} 2-6, \\
\mathrm{H} 2-7, \mathrm{H} 2-8\end{array}$ & $\mathrm{BM}$ & Total breach & $\begin{array}{l}\text { Plugging, bending, } \\
\text { cracking }\end{array}$ \\
\hline \multirow{6}{*}{ U3 } & H3-1 & HAZ & Total breach & Plugging \\
\hline & $\mathrm{H} 3-2$ & WM & $\begin{array}{l}\text { Bullet impact crater, no breach, visible } \\
\text { damage on the rear side }\end{array}$ & - \\
\hline & H3-3 & FL & Total breach & Plugging \\
\hline & $\mathrm{H} 3-4$ & WM & $\begin{array}{l}\text { Bullet impact crater, no breach, visible } \\
\text { damage on the rear side }\end{array}$ & - \\
\hline & $\mathrm{H} 3-5+6$ & $\mathrm{BM}$ & No significant damage & - \\
\hline & $\mathrm{H} 3-7+8$ & $\mathrm{BM}$ & No significant damage & - \\
\hline \multirow[b]{2}{*}{$\mathbf{U} 4$} & $\begin{array}{l}\mathrm{H} 4-1, \mathrm{H} 4-2, \\
\mathrm{H} 4-4\end{array}$ & WM & $\begin{array}{l}\text { Cap weld pass broke away, rest of the } \\
\text { weld without significant damage }\end{array}$ & - \\
\hline & $\mathrm{H} 4-3$ & $\begin{array}{l}\text { WM and } \\
\text { HAZ }\end{array}$ & $\begin{array}{l}\text { Cap weld pass broke away, rest of the } \\
\text { weld without significant damage, HAZ } \\
\text { partially hit, visible damage on rear side }\end{array}$ & - \\
\hline
\end{tabular}

Figure 8 shows the U1 test sample after ballistic testing. Figure $8 \mathrm{a}$ is the front side and Fig. $8 \mathrm{~b}$ is the rear side view. Pictures clearly show that the welded joint did not withstand the ballistic load of the projectiles being shot. Hits H1-2 and H1-3 resulted in total breach through the test sample. Hit H1-1 (Fig. 9) partially breached the weld metal zone. It can be seen on the rear side the occurrence of the smooth bulge. Also hit H1-4 (Fig. 10) resulted in partial breach of the weld metal with the bullet left trapped in the weld metal zone. This sample shows no ballistic resistance in the area of the welded joint. Macrograph of hit H1-1 in Fig. 11 shows the appearance of three mechanisms. First of all, deformation of the "soft" austenitic material layer can be observed as a result of the kinetic energy delivered from the bullet which leads to formation of the crater. Secondly, occurrence of the crack at the end of the HAZ zone where very strong tension appeared. Thirdly, significant sliding of the material 
in the root pass fusion line area caused formation of the bulge on the rear side of the welded joint. Figure 12 shows macrograph of the hit H1-2 which was shot in the area of fusion line and HAZ. Elevation of

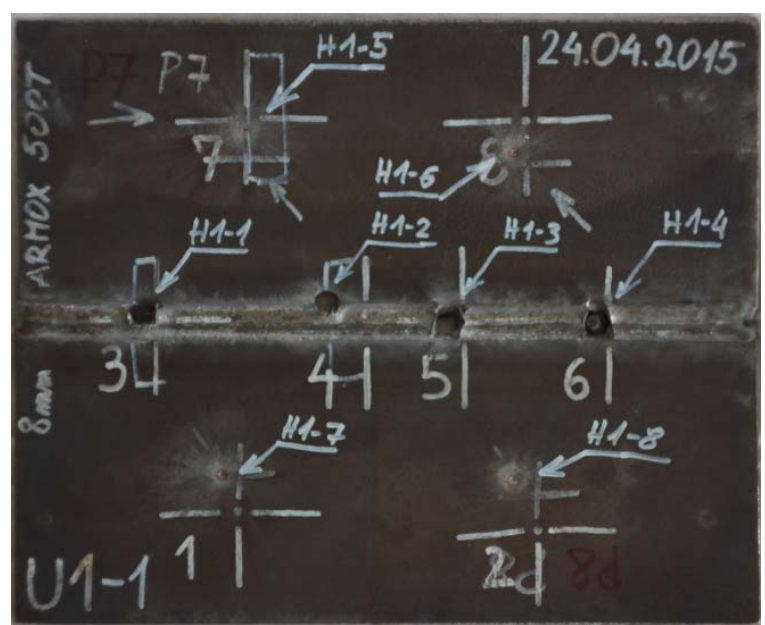

a) front side

Figure 8. U1 sample after ballistic testing.

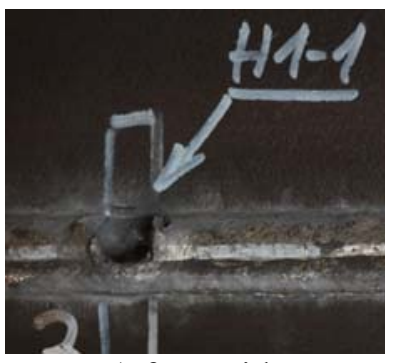

a) front side

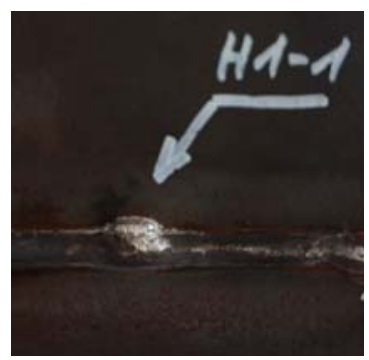

b) rear side
Figure 9. H1-1 hit.

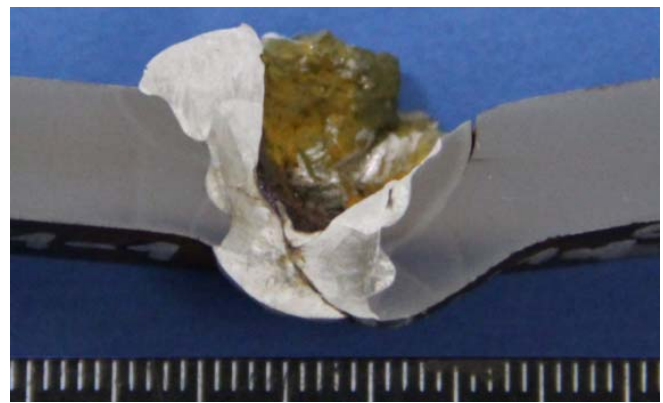

Figure 11. Macrograph of hit H1-1.

Figure 13 displays results of the ballistic testing on sample plate U2. Figure 13a shows the front and Fig. 13b shows the rear side of the test plate. As can be noticed, sample plate U2 did not withstand any of the hits shot at different weld joint zones including the base material. All of the breaches were total the weld metal as a consequence of the pressure waves created when a bullet hit the target can be noticed. This hit clearly shows the extremely low ballistic performance in the area of the HAZ.

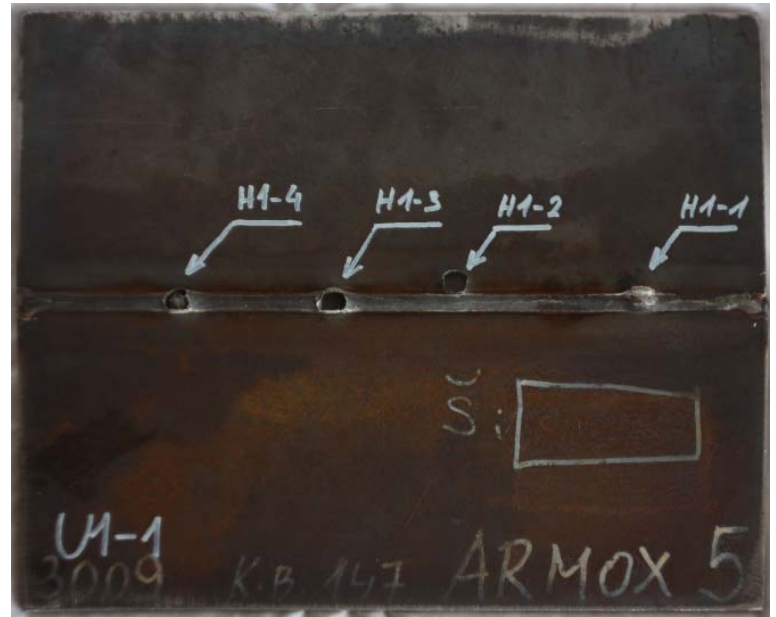

b) rear side

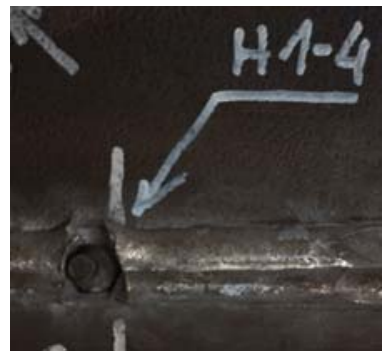

a) front side
Figure 10. H1-4 hit.

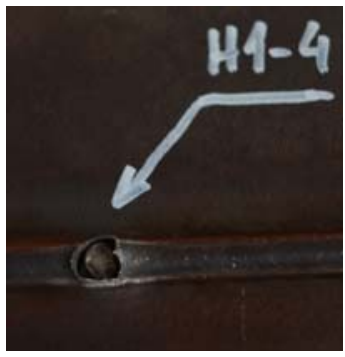

b) rear side

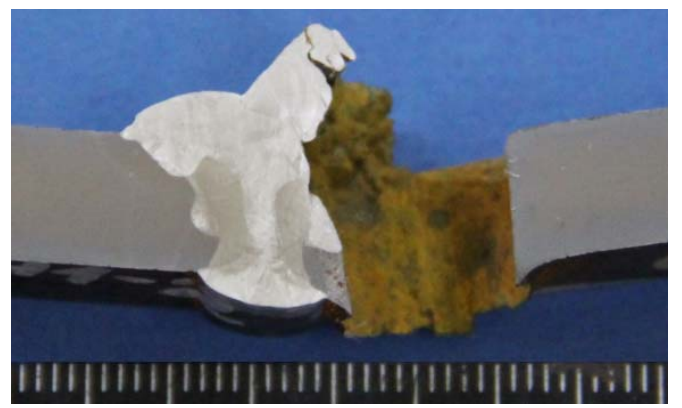

Figure 12. Macrograph of hit H1-2.

breaches with occurrence of plugging. The crack that goes along the weld centre line is due to bullet impacts of hits H2-5, H2-6, H2-7 and H2-8 which were taken with 12.7 munitions type. Figure 14 shows in greater detail H2-2 hit which was shot at fusion line of the welded joint. Figure 14a shows in 
more detail the front side of the hit being shot at the fusion line. The occurrence of the crack can also be noticed along the centre line of the weld metal and chipped off segment of the weld metal due to the H2-2 bullet hit. Macrograph of the H2-2 hit shown

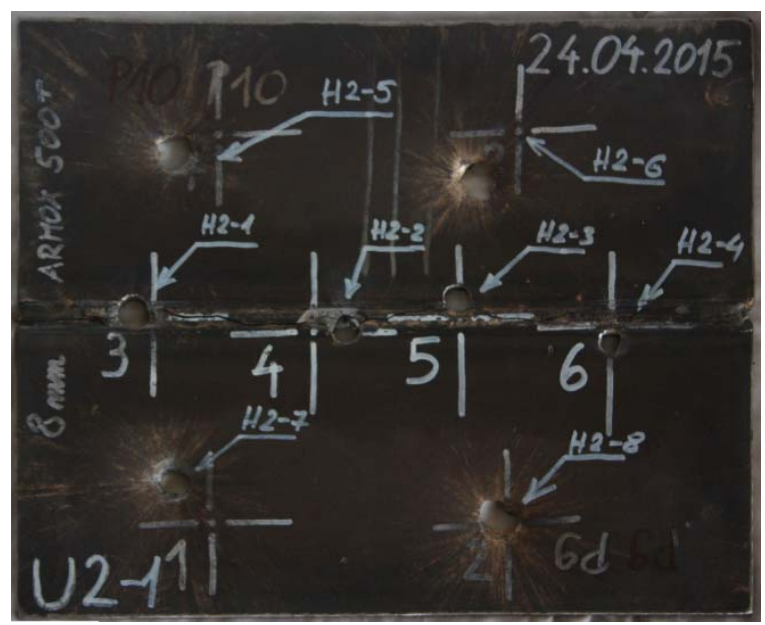

a) front side

Figure 13. U2 sample after ballistic testing.

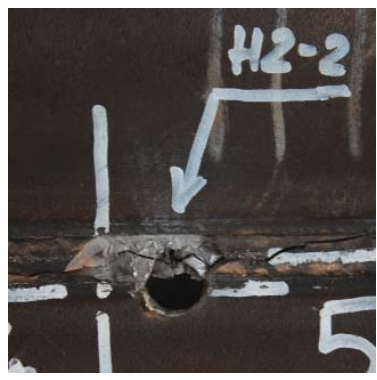

a) front side

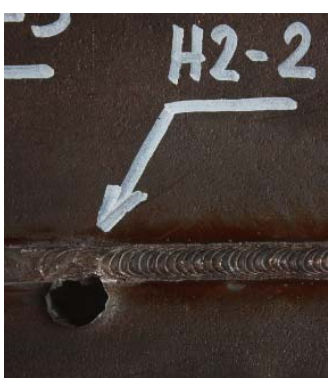

b) rear side
Figure 14. H2-2 hit.

The sample U3 after ballistic testing is shown in Fig. 16. Both front (Fig. 16a) and rear (Fig. 16b) side of the test sample show better ballistic properties in comparison to the samples U1 and U2. Only shots hit to the fusion line and heat affected zone (H3-1 and H3-3) resulted in total breaches. Weld metal (H3-2 and H3-4) resulted in better ballistic performance as there were no breaches but only appearance of the bulges on the rear side. Base material (H3-5, H3-6, H3-7 and H3-8) showed excellent ballistic performance as no significant damage was observed on the front side and on the rear side of the test plate. Figure 17 shows in greater detail hit H3-2 which was made to the weld metal. on the Fig. 15 indicates that the bullet has devastated part of the base material with the left side of the welded joint. Observed crack of the hard filler material indicates the absorption of portion of the load, but not enough to stop the total breach.

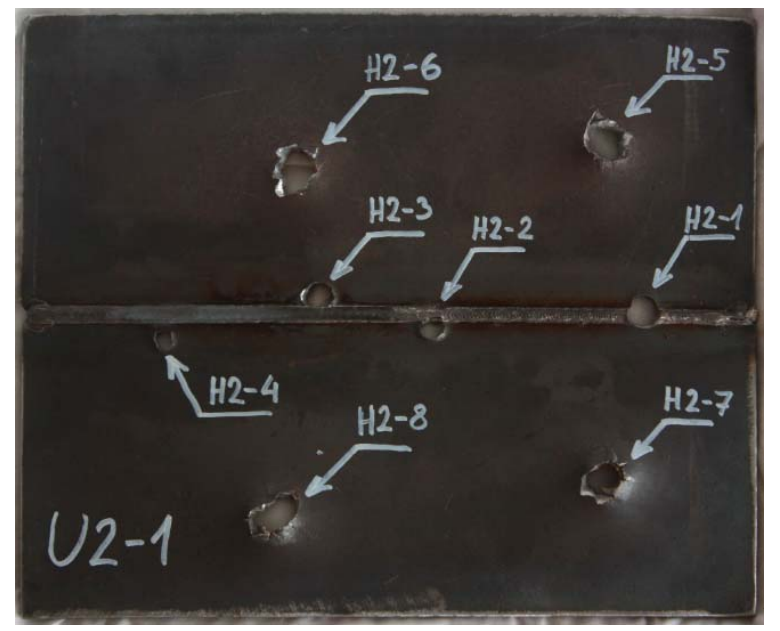

b) rear side

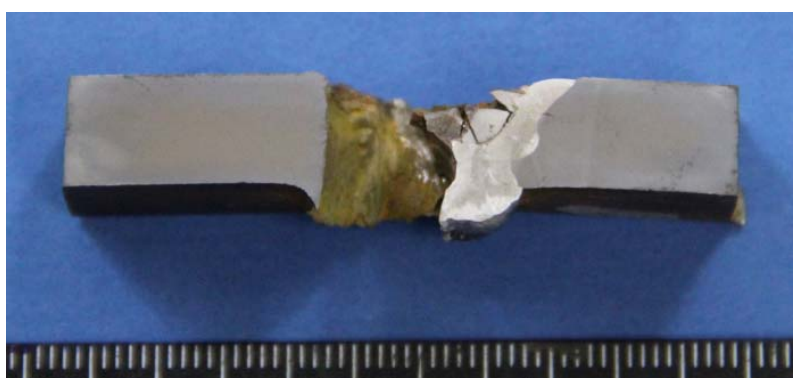

Figure 15. Macrograph of H2-2 hit.

Here it can be seen that the weld metal withstood the great ballistic load of the bullet. No breach was observed but an indent bigger than the bullet occurred. On the rear side only small bulge can be noticed. Macrograph of the H3-2 (Fig 18) shows the damage occurred as a result of the bullet impact wave. Due to the "soft" capping layer, the bullet impact energy has been dissipated blocking further path of the bullet with the "hard" middle layer. This hard layer not only stopped the breach of the bullet through the welded joint but also deflected the bullet to the side. Deflection of the bullet caused the separation of the welded joint in the root layer between the base and filler material. 


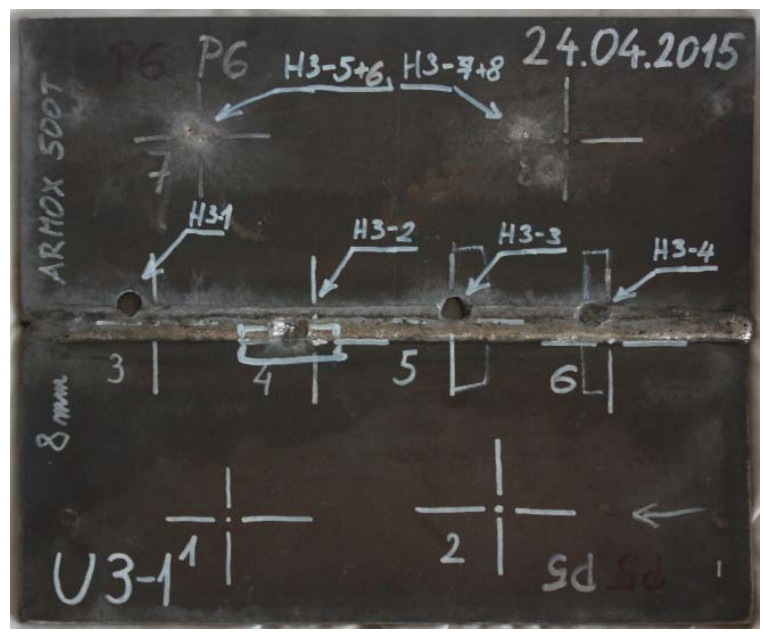

a) front side

Figure 16. U3 sample after ballistic testing.

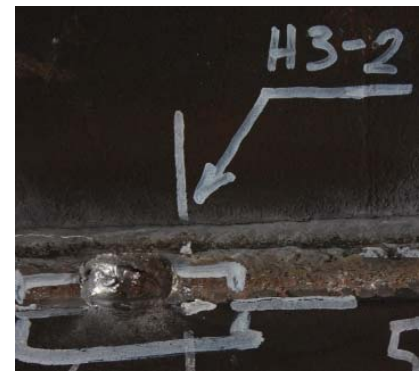

a) front side

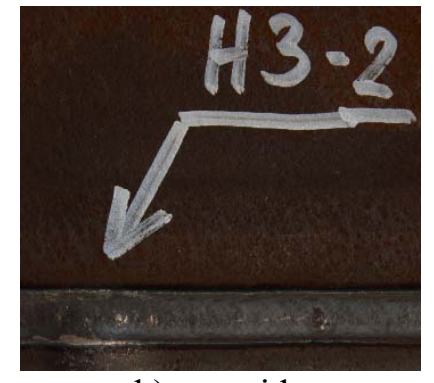

b) rear side
Figure 17. H3-2 hit.

Last sample ballistically tested was the sample U4 shown in Fig. 19. As it can be seen from the Fig. 19a and Fig. 19b, this sample showed the best ballistic performance. No total breaches were observed, even in the critical weld area of HAZ. All hits fired to the weld metal (H4-1, H4-2 and H4-4) caused only chipping off the capping layer leaving the rest of the welded joint without significant damage. Hit shot at the weld metal and HAZ (H4-3) shown in the Fig. 20 resulted in chipping off a piece of capping layer and an occurrence of a small bulge in the rear side of the plate/joint. Figure 21 shows the macrograph of the hit H4-1 which was shot to the weld metal. The picture clearly shows the chipped off piece of capping layer with the intact rest of the welded joint. The role of the capping hard layer was in this case completely fulfilled as the layer took over most of the impact force from the bullet and distributed the rest onto the more elastic and softer austenitic steel filler material. The hard capping layer spent the majority of the impact force by breaking and detaching from the rest of the weld

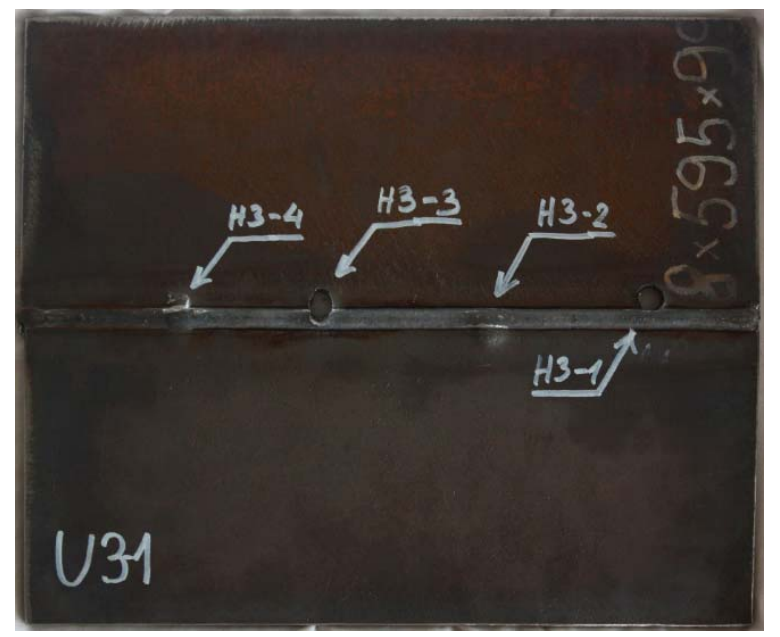

b) rear side

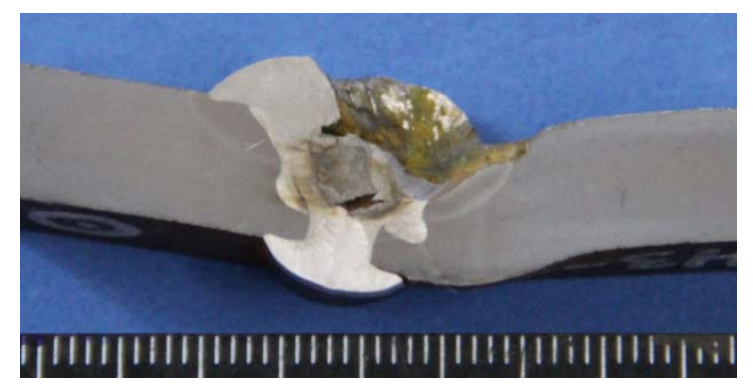

Figure 18. Macrograph of H3-2 hit.

metal and the austenitic filler material beneath the capping layer absorbed the rest of the stress. This kind of stress dissipation left the rest of the welded joint without cracks or any other damages.

\subsection{Hardness}

Hardness of all the samples was carried out in accordance with the HRN EN ISO 6507-1:2008 standard. In every weld layer, 4 measurement indentations were made and average hardness value was calculated. The hardness measurements of the weld metal are shown in Table 5.

Looking at the results displayed in Table 5 it can be seen that some of the values are not quite as expected. Hardness values for the samples U1 and $\mathrm{U} 2$ are in accordance with expectations where the lower values correlate with the austenitic filler material. Using the hardfacing filler material in the sample U2 resulted in hardness value of 830 HV10 which was to be expected. Slightly different readings were noticed in hardness testing of the 
samples U3 and U4. The unusual values are those for weld pass 4 in the sample U3 and weld pass 5 in the sample U4. Those readings are lower than

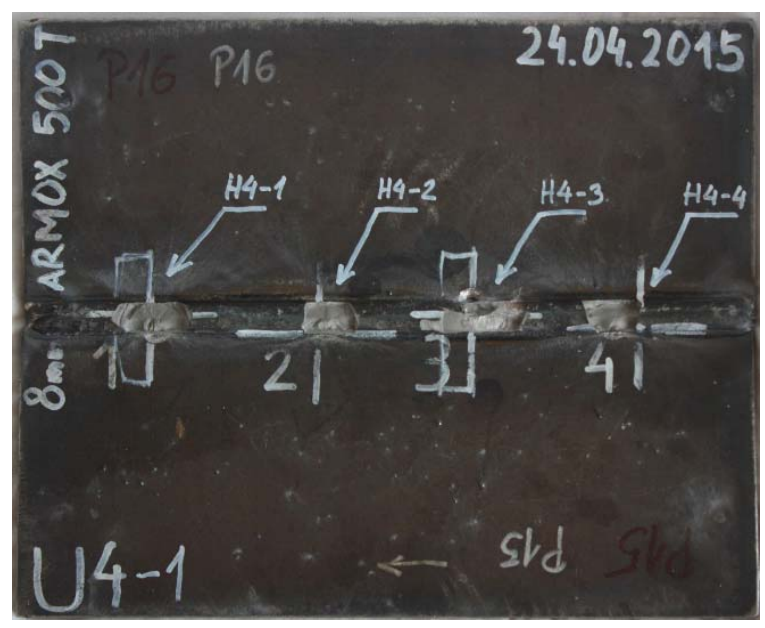

a) front side

Figure 19.The U4 sample after ballistic test.

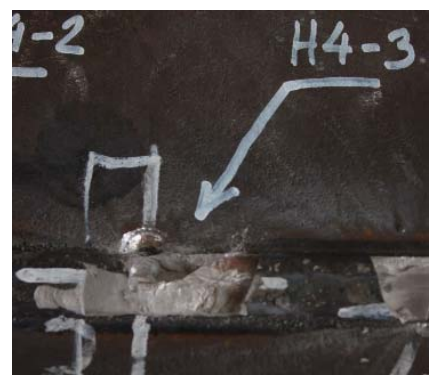

a) front side

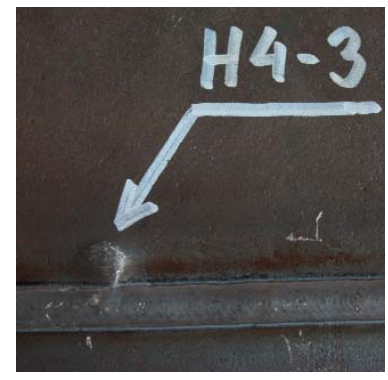

b) rear side

Figure 20. H4-3 hit.

expected (especially for the sample U3) for the used filler material.

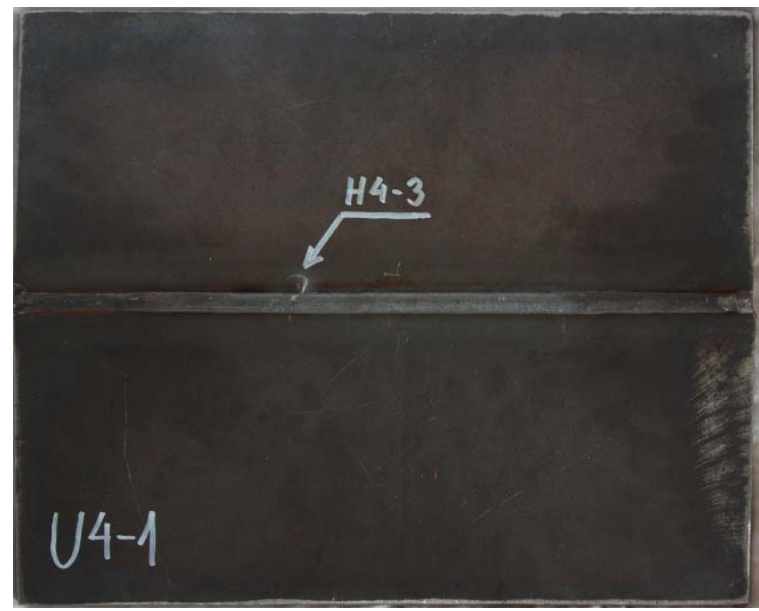

b) rear side

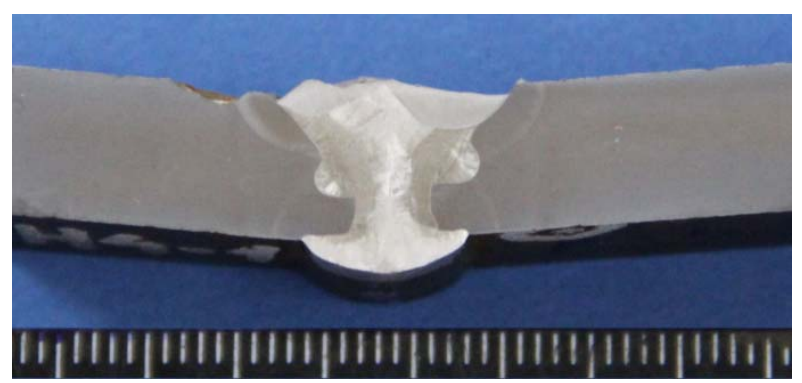

Figure 21. Macrograph of H4-1 hit.

Table 5. Weld metal zone hardness values for the samples U1, U2, U3 and U4

\begin{tabular}{|c|c|c|c|c|c|c|}
\hline \multirow{2}{*}{ Sample } & \multicolumn{7}{|c|}{ Hardness HV10 } \\
\cline { 2 - 7 } & Weld pass 1 & Weld pass 2 & Weld pass 3 & Weld pass 4 & Weld pass 5 & Weld pass 6 \\
\hline U1 & 189 & 192 & 165 & 171 & 146 & 147 \\
\hline U2 & 186 & 190 & 172 & 830 & - & - \\
\hline U3 & 216 & 212 & 180 & 277 & 233 & 167 \\
\hline U4 & 190 & 210 & 192 & 163 & 727 & 861 \\
\hline
\end{tabular}

\subsection{Discussion}

Using the "softer" austenitic filler materials while welding armoured quenched and tempered steel produces welded joint with lower ballistic performance. In this experiment, the filler materials with extremely high hardness, usually used in hardfacing, were used in order to achieve better resistance to ballistic load. Because of the frequent occurrence of hot cracks during welding with the hardfacing filler materials [7], this was avoided by combining the previously mentioned hardfacing filler material with austenitic steel filler material. The austenitic stainless steel filler material was selected because it inhibits the delayed cracking tendency of the Q\&T steel weldments [7]. Also, the use of the ASS filler material prevented the propagation of the crack when it occurred 
improving the dynamic loading resistance during the exploitation.

After evaluating all of the observed experiment results, discussion on the subject of the ballistic performance can be made. First of all, macrographs of all samples (Fig. 4 to Fig. 7) show that there was no occurrence of cracks, inclusions, or porosity indicating that the applied technology was adequately defined. Use of the ASS filler material in combination with the hardfacing filler material prevented the occurrence of hot cracks after welding providing the welded joint with excellent weld integrity. The main difference from standard welded joint is the higher reinforcement of the weld which was not grinded. The reason for keeping the high reinforcement lies in the fact that if it were to be grinded, properties of welded joint would be severely impaired leaving the joint with thinner capping layer which is especially important in the case of hardfacing capping layer.

The sample U1 showed very poor ballistic performance, as it was expected, because the filler material used was low hardness austenitic steel. Almost all of the breaches which occurred were "plugging" type. This type of breach results in extrusion of the material being hit in the form of a plug or cork (Fig. 13). Low ballistic performance was expected due to the use of only low hardness filler material which could not withstand the ballistic impact of the bullet. Only the base material showed good ballistic performance.

Ballistic performance of the sample U2 was even worse than of the sample U1 even though the welded joint consisted of the austenitic steel and hardfacing filler material. The main difference between the sample U2 and other samples was that this sample consisted of fewer weld layers which would obviously contribute to the weld ballistic performance. Even though one might expect better weld characteristics because of the lower total heat input, which means less microstructural changes and mechanical properties deterioration, the results of the ballistic testing proved that it was not the case. It seems that the filler material used in weld metal could not compensate for the deterioration of the mechanical properties due to welding process - heat input.

The sample U3 showed relatively satisfactory results after ballistic testing. Even though there were some signs of damage on the rear side of the welded sample, no breaches were detected. The ASS capping layer overtook some of the bullet impact energy leaving the hardfacing layer to undertake a lower amount of the stress. The results of the hardness of each weld layer in the sample U3 show unexpectedly low values. The reason for this kind of hardness drop can be explained with the fact that the layer with hardfacing filler material went through some extent of heat treatment when the capping layer was welded. This heat treatment obviously caused microstructural changes of the hardfacing layer resulting in the significant drop of hardness values. This sample also showed very low ballistic performance in the area of the heat affected zone where breaches were noticed implying to the deterioration of mechanical properties in this area. The last sample tested was the sample U4. This sample showed the best ballistic performance even though the hardfacing filler material used in welding of this sample was also used in welding of the sample U2. The sample U4 even showed ballistic resistance in the heat affected zone area which was found to be the critical area of the tested welded joints. Hits shot into the weld metal zone and fusion line caused chipping off the piecesof the hardfacing layer. As a consequence of the impact, separation of the chipped off pieces along the fusion line with the weld pass beneath the capping layer occurred. Separation and breaking of the capping layer resulted in distribution of the bullet impact energy. This left the weld pass beneath it without occurrence of cracks providing the welded joint with great ballistic resistance.

According to the literature, projectile penetration resistance of various armour materials is dependent on their hardness. Generally speaking, the harder the material better is the resistance to projectile penetration [6]. This experiment proved that a hard capping layer backed-up by a tough and ductile inner (ASS) layer increased ballistic performance of the welded joint by resisting the impact indentation and absorbing the kinetic energy of the projectile [7]. Not only that the type of a filler material influences the ballistic resistance of the welded join, but it also influences the final combination of the weld passes and filler materials. As it can be seen from the experiment, combination of the ASS capping layer over hardfacing layer (the sample U3) resulted in low ballistic performance. But the combination of the hardfacing capping layer over the ASS weld pass (the sample U4) showed much better resistance to projectile penetration. The problem behind the combination of the ASS capping layer and hardfacing middle pass lies in the fact that 
the hardness of the hardfacing weld pass is significantly lower from the values for that filler material. Heat treatment of the hardfacing layer done by the subsequent capping layer resulted in significant hardness drop leaving the welded joint with several weld passes of low hardness values. This can be then compared to the welded joint of the sample U1 which was welded only with the ASS filler material and resulted in poor ballistic performance.

\section{Conclusion}

This paper systematically investigates the effect of combination of hardfacing and ASS filler material in the ARMOX 500T welded joint. Ballistic testing was performed and in combination with hardness testing, the following conclusions can be provided:

- Subsequent weld layers after welding with hardfacing filler material cause the hardness drop of the hardfacing layer dramatically influencing the ballistic resistance of the entire welded joint.

- All of the samples showed lowered or nonexistent ballistic resistance in the heat affected zone area of the welded joint. Taking into account that this area isn't unneglectable in its size, greater research should be made in order to achieve better ballistic performance of the entire welded joint.

- To achieve the best ballistic performance of the welded joint, a capping layer should be welded with a hardfacing filler material which distributes the impact energy to a greater area and transfers it to the lower hardness weld layer underneath which then absorbs the rest of the energy.

\section{References}

[1] Kuzmikova, L.: An investigation of the weldability of high hardness armour steels, $\mathrm{Ph} . \mathrm{D}$. thesis, Faculty of engineering, University of Wollongong, 2012.

[2] Børvik, T., Dey, S., Clausen, A. H.: Perforation Resistance of Five Different High-Strength Steel Plates Subjected to Small-Arms Projectiles, International Journal of Impact Engineering, 36 (2009), 7, 948-964.
[3] Showalter, D. D., Gooch, W. A., Burkins, M. S., Stockman Koch, R.: Ballistic testing of SSAB ultra-high-hardness steel for armor applications, U.S. Army Research Laboratory, 2008.

[4] Magudeeswaran, G., Balasubramanian, V., Madhusudhan Reddy, G.: Effect of Welding Processes and Consumables on Fatigue Crack Growth Behaviour of Armour Grade Quenched and Tempered Steel Joints, Defence Technology, 10 (2014), 1, 47-59.

[5] Magudeeswaran, G., Balasubramanian, V., Madhusudhan Reddy, G., Gopalakrishnan, G.: Experimental Investigation on the Performance of Armour Grade Q\&T Steel Joints Fabricated by Flux Cored Arc Welding with Low Hydrogen Ferritic Consumables, Journal of Materials Science and Technology, 25 (2009), $5,583-591$.

[6] Balakrishnan, M., Balasubramanian, V., Madhusuhan Reddy, G., Sivakumar, K.: Effect of Buttering and Hardfacing on Ballistic Performance of Shielded Metal Arc Welded Armour Steel Joints, Materials and Design, 32 (2011), 2, 469-479.

[7] Balakrishnan, M., Balasubramanian, V., Madhusudhan Reddy, G.: Effect of Hardfacing Consumables on Ballistic Performance of $Q \& T$ Steel Joints, Defence Technology, 9 (2013), 4, 249-258.

[8] Balakrishnan, M., Balasubramanian, V., Madhusudhan Reddy, G.: Effect of PTA Hardfaced Interlayer Thickness on Ballistic Performance of Shielded Metal Arc Welded Armor Steel Welds, Journal of Materials Engineering and Performance, 22 (2013), 3, 806-814.

[9] Madhusudhan Reddy, G., Mohandas, T., Papukutty, K.: Enhancement of Ballistic Capabilities of Soft Welds Through Hardfacing, International Journal of Impact Engineering, 22 (1999), 8, 775-791.

[10] Babu, S., Balasubramanian, V., Madhusudhan Reddy, G., Balasubramanian, T. S.: Improving the Ballistic Immunity of Armour Steel Weldments by Plasma Transferred Arc (PTA) Hardfacing, Materials \& Design, 31 (2010), 5, 2664-2669 